\title{
OPEN INNOVATION AND BUSINESS MODEL: EMBRAPA FORESTRY CASE STUDY
}

\author{
FILIPE C. VIEIRA ${ }^{1}$ \\ (iD) https://orcid.org/0000-0003-1000-4470 \\ HAMILCAR V. DO VALE \\ (iD) https://orcid.org/0000-0002-2533-8169 \\ MÁRCIA R. MAY \\ (iD) https://orcid.org/0000-0002-3644-9980
}

To cite this paper: Vieira, F. C., Vale, H. V., \& May, M. R. (2018). Open innovation and business model: Embrapa forestry case study. Revista de Administração Mackenzie, 19(4). doi 10.1590/16786971/eRAMR180011

Submission: Feb. 01, 2018. Acceptance: May. 28, 2018.

1 Universidade Positivo (UP), Curitiba, PR, Brazil.

2 Centro Universitário Opet (UniOpet), Curitiba, PR, Brazil.

3 Universidade Federal do Paraná (UFPR), Curitiba, PR, Brazil.

\section{(cc) BY




\section{ABSTRACT}

Purpose: To understand how Embrapa Forestry Unit structure its business model to manage better the issues inherent to open innovation, oriented to the management of technology, science delimiting the elements of business models, and inbound and outbound open innovation and their aspects related to impact model.

Originality/value: Embrapa Forestry is a research unit focused on technological research in the commercial and non-commercial forestry sector. The central objective of this work was to evaluate how a public company manages its business model in the practical exercise of open innovation.

Design/methodology/approach: In order to understand the company's business model, we adopted the perspective of triangulated single case study between semi-structured interviews and secondary data review based on reports and memos. This is all due to the technological relevance that used open innovation to design a model that today we understand as business models and impact business model, with the data collected and analyzed using the Atlas.ti software.

Findings: The results indicate that the importance of Embrapa in the technological scenario in Brazilian agriculture has a significant socioeconomic impact. As a variant, we recognize that, for future research, other theoretical models could be used or adapted to the Brazilian empirical context to understand other organizational elements not addressed in the present study, which can explore cultural relations of the organization and the constitution of sense and meanings in the context of the innovation in public research companies.

\section{KEYWORDS}

Open innovation. Business model. Impact model. Public organization. Agroforestry sector. 


\section{INTRODUCTION}

The reality experienced by organizations, in addition to demonstrating the inevitability of innovating, is demonstrative of the need to identify how companies will lead their innovative processes. From this perspective, Chesbrough (2003) presented the concept of open innovation (OI). OI has been discussed from a number of perspectives, including its strategic importance. For this study, the proposal by Schillo and Kinder (2017) was selected, evaluating OI aligned with the perspective of the Business Model (BM) in organizations (Chesbrough, 2003; Enkel, Gassmann, \& Chesbrough, 2009).

As companies are becoming more dependent on external sources, the adoption of OI has become inevitable (Foss \& Saebi, 2016; Laursen \& Salter, 2006). Therefore, by linking these themes, organizations integrate and commercialize resources beyond their organizational frontiers (Laursen \& Salter, 2006), demonstrating a new form of creating and capturing value.

In this context, Teece (2010b) claimed that technological progress is changing firms and how they make commercial transactions and the delimitation of the characteristics of sectors. Essentially, from an OI perspective, when companies innovate, they form relationships, detect opportunities, reconfigure their capabilities, competencies, business model, and resources. This leads to the internal and external creation and transfer of knowledge (Ceretta, Reis, \& Rocha, 2016; Chesbrough \& Rosenbloom, 2002; Chesbrough, 2012; Lichtenthaler \& Lichtenthaler, 2009).

Although the topics in this study have been discussed in a number of ways in the international literature, there is a research gap involving empirical studies in the context of public companies, in accordance with the special call of the Journal Government Information Quarterly in 2016, as research has mostly concentrated on private companies. In this sense, Enkel et al. (2009), Feller, Finnegan, and Nilsson (2011), Freitas and Dacorso (2014), and Kankanhalli, Zuiderwijk, and Tayi (2017) have stated that, in addition to private sector companies, public organizations are increasingly seeking to engage in OI. According to the authors, the practice of OI in the public sector generally requires alignment between the demands of society and public policies by the authorities.

Although cooperation between companies, universities and research centers occurs on an informal basis, for some time now, at the national level, governments have been developing mechanisms to strengthen this interaction, such as Brazilian Law 10.973 of 2004, known as the Innovation Law. 
Although the determinants of interaction have been extensively studied, little attention has been paid to how governmental organizations manage their business models. However, it should be emphasized that public sector organizations are in the early stages of adopting OI (Kankanhalli et al., 2017), which justifies the present study.

Of the sectors involved in this scenario, the agroforestry sector, which has evolved in the context of practicing OI, requires further study. Innovation, in technology or in processes, has enabled significant advances in this sector, especially increased productivity (Vieira Filho, 2009).

According to Vieira Filho (2009), the agroforestry sector is a receptor and propeller of innovation. To this researcher, an extensive part of technological research and development is conducted by public research institutes, public and private universities, private institutions and industries operating in the market. Therefore, the State plays an important role in generating and promoting technologies, knowledge, and innovation in Brazil. In this respect, Vieira, Buainain, Torres, and Contini (2015),claim that innovation in this market sector has become more complex.

In this sense, it is believed that the Empresa Brasileira de Pesquisa Agropecuária (Embrapa), located in the municipality of Colombo, in Paraná State, has made a positive impact on the development of innovations for the Brazilian agroforestry sector. Therefore, it is necessary to analyze the value delivery process from the perspective of OI in the organization's BM. For this purpose, the present study is based on the following question: How does the Embrapa Forestry Unit structure its business model to manage better the issues inherent to open innovation?

The central aim of this study is to evaluate how a public company manages its business model using open innovation. Specifically, the study is intended to analyze: 1 . the elements of the business model and its roles in employing OI; 2 . internal and external relationships inherent to OI; and 3. aspects related to the governance of transactions and the mechanisms used for OI management (Saebi \& Foss, 2015; Zott, Amit, \& Massa, 2011).

Although there are a number of perspectives responsible for portraying inter-institutional collaboration, OI makes it possible to identify the different forms of interaction and the stages in which this practice may be found, through the business model (Schillo \& Kinder, 2017). Therefore, the present article will focus on this context, seeking to understand how OI is implemented in a Public Research Institute (PRI).

As a variant, we recognize that, for future research, other theoretical models could be used or adapted to the Brazilian empirical context to 
understand other organizational elements not addressed in the present study, which can explore cultural relations of the organization and the constitution of sense and meanings in the context of the innovation in public research companies.

The relevance of this work surrounds the challenges of creating innovation, essentially in the case of a Brazilian public company, which shed light on the understanding that open innovation is an element that underlies the business model and how value is created. The article is structured into five sections, including this introduction. In the second section, the theoretical framework is presented, i.e., the foundations and concepts of the $\mathrm{BM}$ and OI. The third section focuses on presenting the methodological procedures, while the fourth introduces the case to the reader. Finally, the fifth section includes a description and analysis of the data, followed by the main conclusions.

\section{THEORETICAL FRAMEWORK}

With the objective of the study having been stated, this section concentrates on the main conceptual arguments on which the work is based. For this purpose, the theoretical framework is divided into two perspectives: first, the literature on the business model, followed by the main concepts of open innovation.

\subsection{Business model}

First, the researchers argue that there is no clear definition of the concept of the BM, despite the fact that the literature on it stretches back as far as the nineteen fifties (Amit \& Zott, 2001; Osterwalder, Pigneur, \& Tucci, 2005; Osterwalder \& Pigneur, 2010). According to Wirtz, Pistoia, Ullrich, \& Göttel (2015), it was only in the 1990's that scholars of strategy and innovation, involved in Information and Communication Technology (ICT), presented relevant definitions of the BM.

According to Teece (2010a), the term "business model" has no standard definition, mainly because there is no established place in economic theory for business models and there have been few studies on their relationship with business practice.

In this context, Wirtz et al. (2015) identified three large orientation groups for studies related to this theme: 1. technology orientation; 
2. organizational theory orientation; and 3. strategy orientation. Regarding technology, the BM is a technical competence or skill to manage the capability to incorporate procedural alternatives into the business vision. Concerning an analysis at the organizational theory level, the BM is recognized as an interactive factor in the organization that enables a link between the organizational structure and its stakeholders. Considering as a third orientation, the strategy involves the environment and competitiveness as a way to adapt and develop capacities by exploiting environmental contingencies.

Brink and Holmén (2009) and Wirtz et al. (2015) also argued that the main purpose of the $\mathrm{BM}$ is to highlight the competitive advantage of organizations. In short, the respective authors explain the BM as the capability of companies to create value for their commercial partners and, with this, capture value in the market.

The development-oriented BM is conceptualized by Lambert and Davidson (2013) through the contingency theory, which argues that technological trajectories pave the way for new alternatives in products and/ or services, given the set of knowledge.

In fact, this perspective corroborates the premise that there must be a capacity for exploration and exploitation of new alternatives for the creation of value and new technological artifacts. Considering this respect, Johnson et al. (2008) define the BM from four interrelated elements for the creation and delivery of value. The first one involves the delivery of value to the customer, the second is linked to the profit formula, the next is focus on the key resources, and then key process concerns institutional isomorphism, with norms and rules of behavior to enable the recurrent delivery of value.

This portrays a relation of appropriation and absorption of knowledge, resources, and alternatives of innovation that are reflected in the reach of the technological frontiers know as inbound OI. Seen in other words, BM supports, when employed by the perspective of OI, the exploration of new technological alternatives, solutions that, a priori, are outside the organization, but not exclusively.

In this line of reasoning, Teece (2010a) understands that the BM can be used as a platform to connect suppliers, resources, and processes, resulting in a competitive advantage for the organization. According to Chesbrough (2012, p. 79), the scientific literature recognizes that the "the business model is a useful framework to link ideas and technologies to economic outcomes". Although the definitions may vary from one study to another, most come close to that of Teece (2010a, p. 172), that "the business model describes the design or architecture of the value creation, delivery, and 
capture mechanisms an enterprise employs". In other words, the proposal of value, target segments, value chain and capture of revenues are included in many definitions of a BM.

It should be highlighted, based on Massa et al. (2017), that value creation, from the viewpoint of the traditional theories of strategy, such as the Resource-Based View (RBV), is characterized as a phenomenon in which value is created exclusively by producers, with no involvement from customers.

With the BM analyzed mainly in a private context, it is then presented in a public environment, thus justifying the investments by government in R\&D. Schillo and Kinder (2017) proposed the equivalent of the BM for the public sector, known as the "Impact Model" (IM). Indeed, like the BM, the Impact Model articulates value creation and capture by governments, with the aim of making a positive impact on the social context.

To complement this, the BM concept proposed by Chesbrough (2006) and the model used by Schillo and Kinder (2017) in the IM context are shown in Figure 2.1.1.

\section{(Figure 2.1.1)}

FUNCTIONS OF THE BUSINESS AND IMPACT MODEL

\begin{tabular}{ll}
\multicolumn{1}{c}{ Business Model } & \multicolumn{1}{c}{ Impact Model } \\
\hline $\begin{array}{l}\text { Articulate the value proposal, i.e., the value } \\
\text { created for users, through supply based on } \\
\text { technology }\end{array}$ & $\begin{array}{l}\text { Articulate the value proposal, i.e., the value } \\
\text { created in relation to society's priorities }\end{array}$ \\
\hline $\begin{array}{l}\text { Identify a market sector, i.e., the users of the } \\
\text { innovation }\end{array}$ & $\begin{array}{l}\text { Identify the interested parties, i.e., the part of } \\
\text { society that would use the innovation }\end{array}$ \\
\hline $\begin{array}{l}\text { Define the value chain structure required by } \\
\text { the enterprise to create and distribute supply, } \\
\text { and determine the complementary assets } \\
\begin{array}{l}\text { needed to support the position of the company } \\
\text { in the chain }\end{array}\end{array} \quad \begin{array}{l}\text { Define the value chain structure required to } \\
\text { achieve an impact on the interested parties }\end{array}$ \\
$\begin{array}{l}\text { Specify the revenue generation mechanism } \\
\text { and estimate the cost structure and profit } \\
\text { potential, given the value proposal and the } \\
\text { value chain }\end{array}$ & $\begin{array}{l}\text { Specify mechanisms that make an impact and } \\
\text { outline the cost and mechanism structure, } \\
\text { given the value proposition and value chain } \\
\text { structures }\end{array}$ \\
\hline
\end{tabular}




\section{(Figure 2.1.1 (conclusion))}

FUNCTIONS OF THE BUSINESS AND IMPACT MODEL

\begin{tabular}{ll}
\multicolumn{1}{c}{ Business Model } & \multicolumn{1}{c}{ Impact Model } \\
\hline $\begin{array}{l}\text { Describe the company's position in the value } \\
\text { chain, when linking suppliers and customers, } \\
\text { including the identification of partners and } \\
\text { competitors }\end{array}$ & $\begin{array}{l}\text { Describe the position of the public research } \\
\text { institute in the regional innovation } \\
\text { system, linking the research institutes, } \\
\text { associations, enterprises, individuals and } \\
\text { interested parties internationally; identify } \\
\text { partners for the innovative process, whose } \\
\text { goal is to bring benefits to the market sector } \\
\text { and society }\end{array}$ \\
\hline $\begin{array}{l}\text { Formulate the competitive strategy through } \\
\text { which the innovator will gain and sustain a } \\
\text { competitive advantage over its competitors }\end{array}$ & $\begin{array}{l}\text { Formulate the impact strategy through which } \\
\text { the laboratory will continue to anticipate } \\
\text { opportunities to add value, reduce risks and } \\
\text { avoid competition with the private sector }\end{array}$ \\
\hline
\end{tabular}

Source: Adapted from Chesbrough (2012, p. 80) and Schillo and Kinder (2017).

In this matter, the theoretical perspective that we adopt is supported in bases understood between the traditional BM and the IM. The conciliation that is sought to stablish is how the Embrapa Forestry Unit has structured $\mathrm{BM}$ to manage better the issues inherent to open innovation in the bourne and roles adopted in the extensions of the inbound OI dimension and their premises of management and governance. Meanwhile, IM prioritizes the creation of value in favor of society and those who can employ the technological benefits of innovations (Kankanhalli et al., 2017). Then, it emerges a new vision of value creation structure that supports public institutions to benefit society at large. For these reasons, there are specific mechanisms that are qualified to overcome infrastructure costs in order to propose value in a new innovation system. Therefore, IM operational entities are research institutes, associations, companies, individuals, or interested parties that reach mutual benefits.

However, the BM and IM must be alienated from the ability to access new resources, knowledge, and practices that must be obtained by OI when the open inbound innovation is reached.

Having completed the conceptual analysis of the literature, the next step is the characterization of the OI process in the following subsection. 


\subsection{Open innovation}

In this perspective, a number of works have taken this path, such as Schumpeter (1982), Nelson and Winter (1982), Dosi (1982), Chesbrough (2003), and Pitassi (2012).

In this environment of constant dynamics, the term "Open Innovation" emerged, coined by Chesbrough (2003). Therefore, to understand its principles, it is necessary to recall Closed Innovation (CI). According to Chesbrough (2004), CI requires absolute control by the company, emphasizing that companies should be self-sufficient, given the uncertainty of quality, availability, and capacity of the ideas of third parties, i.e., commercial partners (Chesbrough \& Bogers, 2014). Through this prism, Van Der Meer (2007) and Lichtenthaler (2008) claim that this paradigm restricts the innovative process within the organizational limits.

Due to the limitations of the contemporary business environment and the CI paradigm, companies began to seek a new way to manage the innovation process. The result, according to Chesbrough (2012), was the open innovation model. In this work, the researcher compares the respective models and their principles, shown in Figure 2.2.1.

\section{(Figure 2.2.1)}

\section{PRINCIPLES OF CLOSED INNOVATION AND OPEN INNOVATION}

\begin{tabular}{l|l}
\hline \multicolumn{1}{c|}{ Principles of Closed Innovation } & \multicolumn{1}{c}{ Principles of Open Innovation } \\
\hline The best in our field work for us. & $\begin{array}{l}\text { Not all the best work for us. We need the best } \\
\text { professionals in and outside of our company. }\end{array}$ \\
\hline $\begin{array}{l}\text { To profit from R\&D, we have to discover, } \\
\text { develop and achieve results ourselves. }\end{array}$ & $\begin{array}{l}\text { External R\&D can create significant value. } \\
\text { Internal R\&D is necessary to achieve a certain } \\
\text { part of this value. }\end{array}$ \\
\hline $\begin{array}{l}\text { When it is our discovery, we will always launch } \\
\text { it on the market first. }\end{array}$ & $\begin{array}{l}\text { We are obliged to conduct research to profit } \\
\text { from it. }\end{array}$ \\
\hline $\begin{array}{l}\text { The first company to launch an innovation on } \\
\text { the market always retains this market. }\end{array}$ & $\begin{array}{l}\text { Building a better business model is more useful } \\
\text { than being the first to reach the market. }\end{array}$ \\
\hline $\begin{array}{l}\text { If we create the best and most ideas in the } \\
\text { industry, success is guaranteed. }\end{array}$ & $\begin{array}{l}\text { If we use internal and external ideas, success } \\
\text { will be ours. }\end{array}$ \\
\hline $\begin{array}{l}\text { We need to have control of our intellectual } \\
\text { patents so that the competition cannot } \\
\text { benefit from our ideas. }\end{array}$ & $\begin{array}{l}\text { We have to produce revenue through the third- } \\
\text {-party use of our patents, and we have to buy } \\
\text { patents from third parties whenever this can } \\
\text { improve our business model. }\end{array}$ \\
\hline
\end{tabular}


Specifically, the OI model "changes the role of the research function" and can lead a company to success on two different paths: 1 . innovations that originated internally, within the frontiers of the organization; and 2. through innovations conceived outside its frontiers. Therefore, "knowledge located from outside may be just as useful as knowledge created from within" (Chesbrough, 2003, p. 68; Van Der Meer, 2007). According to Chesbrough (2003, p. 1), the definition of OI is "intentional use of inflows and outflows of knowledge to accelerate internal innovation and expanding markets for external use of innovation, respectively".

In this sense, Laursen and Salter (2006) infer that the aim is to accelerate internal innovation and, consequently, expand markets for the innovation to be used. Thus, admitting external sources of technology does increase the number of possible sources of innovation (Chesbrough, 2003).

Although OI has attracted the attention of academics in relation to the private sector, it also means benefits when applied in the public sector (Kankanhalli et al., 2017). Moreover, public organizations retain distinct characteristics, showing the need to study the theme in a public organizational context. Figure 2.2.2 shows a possible distinction between the practice of OI in public and private sectors in terms of focus, target, aims and value.

(Figure 2.2.2)

DIFFERENCES BETWEEN OPEN INNOVATION IN THE PRIVATE AND PUBLIC SECTORS

\begin{tabular}{lll} 
& \multicolumn{1}{c}{ Private Sector } & \multicolumn{1}{c}{ Public Sector } \\
\hline Focus & New products and service development & Normally not an artifact \\
\hline Target & $\begin{array}{l}\text { Mainly initiated for competitive } \\
\text { advantage }\end{array}$ & $\begin{array}{l}\text { Driven by the goal of improving } \\
\text { service performance }\end{array}$ \\
\hline Value & Adding value in terms of higher revenue & $\begin{array}{l}\text { Adding value in terms of benefits to } \\
\text { society }\end{array}$ \\
\hline Stakeholders & Competitors, partners, institutions, & $\begin{array}{l}\text { Citizens, intermediaries, universities, } \\
\text { other government organizations, } \\
\end{array}$ \\
& organizations, and other industries & private sector industries, and non- \\
& & profit organizations \\
\hline
\end{tabular}

Source: (Kankanhalli et al., 2017, p. 2).

In the public context, the basis is normally centred on: 1 . changes in the form and content of services when including problems in public policies 
to solve them; 2 . improving the performance of services and adding value to society, i.e., promoting greater awareness of social problems; and 3. the fact that OI in the public sector goes beyond the focal organization. In this way, the public sector expands the field of OI.

\section{METHODOLOGY}

The present work is based on exploratory and descriptive structures, using qualitative research as suggested by Yin (2010). According to Creswell (2010), this is because the qualitative approach is chosen with a view to highlighting characteristics that are unobservable and unreachable through quantitative study. Furthermore, the study is considered exploratory because it seeks information that has not been very well developed in the research context (Collis \& Hussey, 2005; Creswell, 2010). Thus, it seeks to understand and report the terms involved in the phenomenon, enabling data to be interpreted and enhancing existing studies (Marconi \& Lakatos, 2003). The argument of Collis and Hussey (2005) that descriptive research allows the portrayal of details that comprise the phenomenon should be highlighted, as it enables this study to be characterized as such.

This is a single case study (Yin, 2001), evaluating how Embrapa Forestry, a public sector company, manages its business model when practicing open innovation with its partners (Eisenhardt, 1989). The aforementioned authors also note that the case study is recommended for research that seeks to explore "how" and "why" a certain situation occurs.

The Embrapa Forestry Unit is important because it has introduced a significant number of processes, technologies, and services to the market, since it was founded in the mid 1970's, enabling greater productive efficiency, creating jobs and incoming and improving environmental conservation. It should also be highlighted that because of the efficient technology transfer process, the work of the Embrapa Forestry Unit has been recognized by a number of institutions (Otto, Iede, \& Junior, 2009). Therefore, in accordance with Yin (2001), the use of the case study is justified once again, considering that a unique case of the Brazilian agroforestry market is being addressed. Nevertheless, Yin (2001) argues that, in single case studies, data triangulation should be prioritized. In keeping with this argument, Creswell (2010) points out the importance of employing different elements in data collection. The researcher's highlight that data triangulation results in a more robust study, i.e., the information 
obtained should be compared so that the conclusions drawn from the study are prudent.

As suggested by Yin (2001), data collection in qualitative research includes obtaining information through semi-structured interviews with researchers and department heads in Technology Transfer, R\&D, and the General Management of the unit, in addition to documents, archived files and non-participant observation, which were used in the study (Figure 3.1).

In addition, the interviews were collected during the months of August to October 2016 and happened in the branch of the unit of Embrapa forestry in Colombo, Paraná. We started with an integration briefing run by the human resources department of Embrapa Floresta unit. Interviews were conducted with the executives, who detailed their experiences in the case related to the development of the Sirexwoodwaso (Sirex Noctilio) solution. It should be noted that the set of interviews was limited because we focused on interviewing those executives who were originally the researchers, assistants, operation managers in the past, and now executives and chief in research.

Moreover, the interviews were recorded and later transcribed so that they were processed in Atlas.ti 7, whose objective was to classify the affirmations alleged by the managers. We developed an extensive classification grid based on the BM, IM and OI constructs. These constructs were based on the definitions stated in Figures 2.1.1 and 2.2.1, which we consider as theoretical features. In addition, the remarks of the distinction between private and public sectors were within the thematic of OI.

The Atlas.ti 7 was used as a tool for content analysis of the transcripts originated from the information provided by the executives. This, according to Friese (2012), is a valid procedure, in which she suggests the employment of Atlas.ti for qualitative data analysis enabling the construction of a major view of the constructs and de reality, been supportive to sew the triangulation with the secondary data which was gotten from the Embrapa forestry library; with the crossing data we could purge biases in recognition of the image being researched.

We limited to six respondents inasmuch as based on the fact that these informants who hold management positions these days were the researchers at the beginning of the project two decades ago. As their narratives become repetitive to illustrate the case, we adopted as a methodological premise to consider that six interviewed would be sufficient as well, those interviewed possess reassurance power about that information which translates accuracy about those events (Alshenqeeti, 2014; Eisenhardt, 1989). 
(Figure 3.1)

DATA COLLECTION TECHNIQUES

\begin{tabular}{|c|c|c|}
\hline Unit of Analysis & Data collection techniques & Informants \\
\hline Head & \multirow{3}{*}{$\begin{array}{l}\text { In-depth interview, non-participant } \\
\text { observation, and analysis of organizational } \\
\text { documents. }\end{array}$} & Head \\
\hline $\begin{array}{l}\text { Assistant head of Research } \\
\text { and Development }\end{array}$ & & $\begin{array}{l}\text { Assistant Head } \\
\text { Researcher II } \\
\text { Technician III }\end{array}$ \\
\hline $\begin{array}{l}\text { Assistant Head of } \\
\text { Technology Transfer }\end{array}$ & & $\begin{array}{l}\text { Assistant Head } \\
\text { Analyst III } \\
\text { Analyst II }\end{array}$ \\
\hline
\end{tabular}

Source: Elaborated by the authors.

Finally, it should be emphasized that secondary data were also used, that were available on the company website or obtained during the interviews. The semi-structured interview was based on a minimum script of questions. The purpose of this format was to give the interviewees more freedom to discuss unanticipated subjects, given the less rigid profile (Yin, 2001). To complement this, content analysis was used. According to Strauss and Corbin (2008), this is a set of techniques that enable an analysis of what was communicated through objective and systematic processes.

Finally, to begin the analysis and discuss the results, the interviews were transcribed. In the next section, the case study and the analysis and discussion of the results are presented.

\section{ANALYSIS OF THE RESULTS OF THE CASE STUDY}

\subsection{Embrapa Forestry Unit}

This section presents and articulates the results observed in the data collection at the Embrapa Forestry Unit in the Brazilian's state of Paraná, through the case study.

First, according to the documents made available by Embrapa Forestry, forest research began in Brazil with the creation of the National Forest Research Program (PNPF), the result of contacts between Embrapa and the Brazilian Institute of Forest Development (IBDF), delegating the coordination, execution and support for national forest research to Embrapa. 
Company documents report that in March 1978 the Brazilian Federal Government implemented the Embrapa Agricultural Research Cooperative System. Its coordinators were located at Embrapa's head office in Brasilia, Distrito Federal. Regarding the origin of the unit, in the mid-1984, the Central and Southern Regional Forest Research Unit (URPFCS) was established in the town of Colombo, in the State of Paraná. At that time, its responsibility was to promote, encourage and conduct research in the states of Bahia, Espírito Santo, Minas Gerais, Mato Grosso do Sul, Rio de Janeiro, São Paulo, Paraná, Santa Catarina and Rio Grande do Sul. In December of that year, the Unit was renamed to National Forest Research Center (CNPF), which coordinated all forest research with the Ministry of Agriculture, Livestock, and Supply (Mapa).

The company's mission was to "find solutions through research, development, and innovation to achieve the sustainability of the forests to benefit Brazilian society" (Otto et al., 2009, p. 9). Furthermore, the unit became famous for its excellence based in technology and innovation with regard to sustainable use of Brazilian biodiversity. This was in keeping with Otto et al. (2009), who claimed that innovation enables greater productivity, lower production costs and a positive impact on society by creating jobs and wealth.

Initially, the process of creation of value was evident to all interviewees inasmuch as of the crystal clear notion that Embrapa Forest's role was to create innovations that protect, and develop the timber industry. Concerning the capacity to create innovation to benefit society, Embrapa Forestry has a number of partnerships, according to the research report prepared by Otto et al. (2009), including partnerships with research institutions, universities, funding agencies and domestic and international private companies, justifying once again the importance of OI and the BM used by the organization.

In this case, it is emphasized that only the cooperation between the Embrapa and the wood industry made it possible, because without constituting the technical capacity of Embrapa together with the financial resources of the National Control Fund of the Vespa-da-Madeira (Funcema) and the governmental mobilization for awareness, advertisement and granting among municipalities for technical support, it would not have been possible to construct a business model which overcomes the challenges posed by the woodwasp crisis.

It is important to mention the strategic positioning and that Embrapa Forestry has relationships with a number of sectors. Regarding the organizational vision, the institution defines it as "a center of excellence 
in the generation of knowledge, technology, and innovation for the sustainable production and conserved use of Brazilian biodiversity" (Otto et al., 2009, p. 9).

\subsection{Embrapa's business model}

With the purpose of describing elements of the BM suggested by Schillo and Kinder (2017), and how Embrapa Forestry manages it, the following topics of discussion are presented here: the value proposition, interested parties, value chain, impact, the position of the public research institute and the impact strategy.

\subsubsection{Value proposition}

The value proposition is how the PRI creates value for society (Schillo $\&$ Kinder, 2017). In this context, the structure of Embrapa Forestry and its $\mathrm{BM}$ consider its significant roles in national R\&D, such as the economic inclusion and agroforestry activities.

Embrapa's value proposition became evident in the study. It is characterized as "to deliver to society the results of technological research conducted here, seeking the economic, social and environmental welfare of Brazil" (interviewee). The value proposition of the unit is to advance knowledge. This has a substantial influence on the size of the activities of Embrapa Forestry.

It is also clear that the value proposition is aligned with OI, through cooperation and alliances to create solutions for Brazilian socio-economic problems specifically in agribusiness. In this respect, a direct relationship can be seen between a number of actors in the rural economy, given their involvement in research conducted by large companies in the agroforestry sector, as well as direct relationships with small and medium-sized rural property owners. This throws light on the construct that $\mathrm{R} \& \mathrm{D}$ can create significant value when it exists internal $R \& D$ that allows it to achieve a certain part of this value in overcoming the technological challenges that underlie open inbound innovation.

The IM for the aforementioned project is intended to guide and structure a new production chain of inputs. The main purpose is to bring new entrepreneurs to the field to increase their income. Returning to Schillo and Kinder (2017, p. 11), the main issues concerning the value proposition "are proactively detected, and the organization strives to align its operations 
within the broader target community". In this impact model, Embrapa follows the guidelines of Chesbrough (2003, p. 124), considering the business model as a necessary architecture for better management of its resources, with a view to creating a platform "to connect and coordinate innovative activities".

The value generation nucleus of this project is the technological package, which includes: 1 . mapping the market; 2 . entrepreneurial potentials; and 3. extraction protocols for a number of inputs used in the pharmaceutical and cosmetics industries. It should be emphasized that the next step in the project is to attract these industries, demonstrating the benefits of using yerba mate as a raw material in their products. Therefore, once again open innovation is practiced, albeit with the project already operational.

In this respect, the organizational culture is aligned with the value proposition of the organization, as it shares with its employees the need to reciprocate society's investment in $\mathrm{R} \& \mathrm{D}$. According to the interviewees, the technological solutions that are developed will aid progress in the agricultural and environmental sectors and help to bridge the gap of socio-economic inequality.

\subsubsection{Interested parties}

Concerning the interested parties, i.e., the users of the innovations, the products are intended for small, medium-sized and large rural property owners, in partnerships with universities, other public and/or private research institutes NGOs and other Embrapa units (Otto et al., 2009). This is further evidence if OI in the organizational BM.

Regarding the needs of the interested parties, these have many sources, such as the strategic position, which seeks to meet the demands of society, the main financer of the organization. In other cases, demand stems from potentially viable economic processes, giving rise to emerging technologies for specific sectors. This is the case of the technology to combat the horntail, a response to the requirement of the pine sector.

With regard to the case study of the BM to combat the Sirexwoodwasp (SirexNoctilio), the target customer is a hybrid composition of private farmers and organizations that produce pinewood. Essentially, the dynamic for controlling the woodwasp provided Embrapa with the knowledge required to find a solution meets the demands of the users of the innovation.

When it comes to delivering the product to customers, the company sends it to properties that are interested in the technology along with manuals 
explaining how to apply it. It should be highlighted that, in certain cases, Embrapa trains rural property owners and technicians from the companies that will use the technology how to best handle the innovation. It should also be mentioned that the company bets on the diffusion of knowledge to operate the technology, as it does not have the capacity to provide constant technical assistance. This is the case irrespective of the size of the property or the characteristics of the individuals involved, whether they are families or companies in the sectors for which the research was intended.

\subsubsection{Value chain}

For the Public Research Institute to have an impact on the interested parties, it has to be aware of the configuration of their value chain. In this sense, even when a PRI is renowned worldwide in agroforestry research, it has to be able to pinpoint the barriers to its expansion, which directly reflect the value chain.

First, it has budget restrictions, as its monetary resources are provided by the federal government, i.e., public resources for research. This leads Embrapa to place importance on the need for alliances and public and private cooperation. These factors are inherent to OI, which is in favor of cooperation in technical and scientific research and development.

Thus, an apparent weakness may be considered an advantage, enabling the unit to become involved in cooperation in its agricultural projects. On the other hand, the IM based on public science is highly dependent on specialized labor, which means that opportunities for the PRI to make greater advances may be costly.

In accordance with the theoretical framework, the role of technology transfer is an important one, as it has a significant impact on the value chain of the organization, as direct contact will be made with the final user of the technology. The purpose of this contact is to present the new technology and gauge whether it meets the customer's expectations. Therefore, Embrapa Forestry proposes the underlying concept of knowledge engineering. This strategy works to connect different fields, to make knowledge operational so that individuals can understand and master the concepts and use the scientific knowledge as an architectural production model for productivity and results.

\subsubsection{Generated impact}

As Embrapa Forestry is a public company and its buying processes are highly bureaucratic, it is necessary to understand the specific nature of each 
product requested from its laboratories. An accurate description is also required from the products and equipment to be purchased. The advisory board also plays an important role, complying with rigid and well-defined protocols to publish information, as the publication of information may have a considerable and irreparable impact on productive sectors.

Another important form of assessing the prospecting of knowledge from users of innovation occurs through internal company analyses. The PRI's researchers use different methods to measure the benefits of an innovative process for the company and the Brazilian society.

Based on Rodigheri, Iede, Penteado, and Reis Filho (2006) and on the interviews, it should be highlighted that Embrapa Forestry seeks to fund around $65 \%$ of its projects, seeking participation from other economic agents. These agents provide monetary resources for laboratory equipment that represent an important part of the assets used by Embrapa.

Embrapa, as a public institution, uses resources from Brazilian society and in benefit of Brazilian society. Indeed, the company works to convert its results into benefits for the nation, with its value proposition creating greater competitiveness in the sector.

As it is a public company, employees are hired through civil service tests. This does not always lead to the hiring of the most competent and experienced researchers. Experience is an important factor in scientific research. Along with practice and professional maturity, it leads to successful research and the evolution of technical knowledge.

A new design is necessary for hiring specialists for scientific research. This will only strengthen the capacity to create new technological solutions and value for the company. Moreover, a new contribution could be made to society by enhancing the labor market chain and technical assistance by understanding that a more extensive production chain tends to influence Embrapa's production chain, which could involve new business sectors and increase the generation of economic value for Brazilian society.

\subsubsection{The position of the Public Research Institute}

The information collected in the present study reveals vertical complementarities in the structure of Embrapa, considering the reports that the research structure is shared beyond the laboratories. The scientists share their knowledge, given the contingencies of each project, as shown in the following interview excerpt: "If Project X requires someone who excels at mathematics or quantitative research, and this researcher is at another unit, he will become involved in the process". 
Thus, the organizational fluidity is based on a culture devoted to research and scientific evolution through formal and informal collaboration. Furthermore, the horizontal complementarity with external companies is another usual alternative. Therefore, providing the legal aspects of recognizing Embrapa's ownership and rights are observed and reserved, partnerships are formed. Consequently, partnerships and alliances form a central pillar of the IM, highlighting the important position of the PRI in the regional innovation system.

Regarding Embrapa's position in the regional innovation system, it should be emphasized that it has ties with other research institutes such as the Commonwealth Scientific and Industrial Research Organization (CSIRO), in Australia, and the Paraná Agronomy Institute (Iapar) and the National Agricultural Technology Institute, in Argentina. Embrapa also has laboratories in countries renowned for R\&D, such as the United States, China, South Korea, and European countries. Embrapa also uses media companies, such as newspapers, and television and radio news broadcasts to raise awareness of the technologies it has developed.

Furthermore, the interviews revealed that the vision of conducting research at Embrapa Forestry is like a "factory", where the innovation process begins, as it is there that the human capital is concentrated, with over seventy researchers with their skills and competences that help them recognized future opportunities. Thus, this department makes Embrapa Forestry a highly important center in the development of a wide range of technologies.

\subsubsection{Impact strategy}

From the perspective of the impact strategy, effectiveness and processes are particularly related to professional legitimacy, competence, and ethics that leading researchers are expected to comply with, in addition to bureaucratic requirements. This is because leading researchers on a project need to gain legitimacy in the eyes of their peers, in terms of their perceived quality as individuals and the technical skills and knowledge they bring to the program they are managing.

The project leader needs to articulate knowledge with his colleagues to develop solutions and work towards the same goals. The leader accesses several levels within the organizational frontiers throughout processes ranging from research and production to evaluation and technology transfer. The development of solutions requires up-to-date skills. 
Based on the information obtained here, it is clear that the development of personal skills is essential. This is equivalent to saying that it is essential for employees to have tacit knowledge, acquired throughout their careers as researchers so that they can continue to anticipate opportunities to add value and reduce the risks inherent to innovation.

Innovation and technology projects have singularities that do not exist in other types of project so that all projects have a beginning, a middle and an end. However, innovation and technology projects should constantly be evaluated and have their own abortion or rejection mechanisms. In this sense, Embrapa sets goals three times a year to evaluate innovation and technology projects. As well as considering the time curve, these controls consider the status of a project. If the intermediate goals are being achieved, the research resources are made available, but if they are not, the project is halted. In short, mechanisms are used to measure the efficiency of the project, i.e., the success/failure of a program must be constantly evaluated with a view to reformulating the impact strategy.

The IM used by Embrapa is structured as an open solution for the development of R\&D by enabling the creation of technology in Brazil that focuses on tropical and subtropical characteristics. This can be seen in the Embrapa Directive Plan and the structure of technology prospecting, which is based on three pillars: 1. public policies in alignment with public policies set by the government; 2 . portfolio projects, responsible for reflecting the intentions and actions of Embrapa on key agricultural activities; and 3. projects of arrangement, which are, in turn, linked to the economic sectors involved in agribusiness. The success of this model, according to the reports, lies in its capacity to adapt and transform to create solutions.

\section{FINAL CONSIDERATIONS}

The motivation of this study is defined by an axis that has been trans-passed by a technological evolution that was not only originated by the desire to create technological solutions but the overcoming of an economic, social and also technological challenge. To consider only open innovation as an assumption for the relationship between BM and IM would underestimate the scientific capacity and effort of our research object. When initiatives and actions to combat Sirexwoodwasp arose in Brazil in the early 1980s, there was no discussion of business models as we are currently discussing, so the impact model we use, essentially based on Kinder (2017) was not a theme to be observed. 
In fact, it is a model that proved to be significantly coherent with the practices and values of Embrapa Forestry. As the articulation of the value proposition that the company brings, it gives priority to the creation of value in benefit to society. It overcomes the hasty exploration of the potential for profit, by a mechanism that impacts multiple stakeholders and it is above all privileges social principles of inclusion and economic sustainability.

At that time, the composition of the value chain structure was composed of reforestation and industrial processing of wood of all sizes, which constituted a fund to finance research; municipalities, the federal government, media chain and international research institute, all mobilized efforts that were already outside the traditional logic of business models. Thus, in this study, the impact model was shown to be the most cohesive model, even though it was empirically employed, whose specific characteristics of value creation emerged. For being an impact-oriented model that overcomes traditional costing mechanisms, or a premature goal of profit for a structural chain of value creation, it can occur in traditional BMs by pressure for results.

The conclusions we reached is that it is a public research institute whose impact must be converted into market and societal benefits simultaneously, so that it is effective in anticipating value creation opportunities, reducing risks and avoiding the waste of resources, competing with the private sector, which operates in another market logic, explicitly known and based on other values assumptions.

The approach adopted here to help public managers improve their open innovation is laudable. The Impact Model shows the positive and negative aspects, thus enabling innovation to continue. Furthermore, the study allows public agents to compare PRIs with international institutes.

However, as well as the merits of the present study, there are also limitations, in that some of the information is not made available for reasons of confidentiality. Another restriction is that only two interviews were conducted with the researchers at the technology transfer department, with no interview with the researcher in charge of the Woodwasp Project.

Finally, some suggestions may be made for future studies. First, other theoretical models could be used or adapted to the Brazilian empirical context to understand other organizational elements not addressed in the present study. The study could also be applied to different institutes in other regions and sectors, gauging the occurrence of these behaviors. In short, there is a need to conduct further and more in-depth studies of the Impact Model at Embrapa Forestry and other units, as it has an important innovation portfolio. 


\section{INOVAÇÃO ABERTA E MODELO DE NEGÓCIOS: ESTUDO DE CASO DA EMBRAPA FLORESTA}

) RESUMO

Objetivo: Compreender como a Unidade Embrapa Floresta estrutura seu modelo de negócios para gerenciar melhor as questões inerentes à inovação aberta, orientada para a gestão de tecnologia, delimitando os elementos dos modelos de negócios e inovação aberta inbound e outbound e seus aspectos relacionados ao modelo de impacto.

Originalidade/relevância: A Embrapa Floresta é uma unidade de pesquisa voltada à pesquisa tecnológica no setor florestal comercial e não comercial. O objetivo central deste trabalho foi avaliar como uma empresa pública gerencia seu modelo de negócio no exercício prático da inovação aberta.

Principais aspectos metodológicos: Para entender o modelo de negócios da empresa, Adotamos a perspectiva de estudo de caso único triangulado entre entrevistas semi-estruturadas e revisão de dados secundários com base em relatórios e memorandos. Tudo isso devido à relevância tecnológica que utilizou a inovação aberta para projetar um modelo que hoje entendemos como modelos de negócios e modelo de negócios de impacto, com os dados coletados e analisados usando o software Atlas.ti.

Síntese dos principais resultados: Os resultados indicam que a importância da Embrapa no cenário tecnológico da agricultura brasileira tem um impacto socioeconômico significativo. Como variante, reconhecemos que para futuras pesquisas outros modelos teóricos poderiam ser utilizados ou adaptados ao contexto empírico brasileiro para compreender outros elementos organizacionais não abordados no presente estudo, que podem explorar as relações culturais da organização e a constituição de sentidos e significados em o contexto da inovação em empresas públicas de pesquisa.

\section{PALAVRAS-CHAVE}

Inovação aberta. Modelo de negócio. Modelo de impacto. Organização pública. Setor agroflorestal. 


\section{REFERENCES}

Alshenqeeti, H. (2014). Interviewing as a data collection method: A critical review. English Linguistics Research, 3(1), 39-45. doi:10.5430/elr.v3n1p39

Amit, R., \& Zott, C. (2001). Value creation in e-business. Strategic Management Journal, 22 (6-7), 493-520.

Brink, J., \& Holmén, M. (2009). Capabilities and radical changes of the business models of new bioscience firms. Creativity and Innovation Management, 18(2), 109-120. doi:10.1111/j.1467-8691.2009.00 519.x

Ceretta, G. F., Reis, D. R., \& Rocha, A. C. (2016). Innovation and business models: A bibliometric study of scientific production on Web of Science database. Gestão \& Produção, 23(2), 433-444. doi:10.1590/0104-530x1 461-14

Chesbrough. (2012). Inovação aberta: Como criar e lucrar com a tecnologia. Porto Alegre: Bookman.

Chesbrough, H. (2003). Open innovation the new imperative for creating and profiting from technology. Boston: Harvard Business School Publishing Corporation.

Chesbrough, H. (2004). Managing open innovation. Research-Technology Management, 47(1), 23-26. doi:10.1080/08956308.2004.11671604

Chesbrough, H. (2006). Open business models: How to thrive in the new innovation landscape. Brighton: Harvard Business School Press.

Chesbrough, H., \& Bogers, M. (2014). Explicating Open Innovation: Clarifying an emerging paradigm for understanding innovation keywords. In H. Chesbrought, W. Vanhaverbeke, \& J. West, New Frontiers in Open Innovation (pp. 1-37). doi:10.1093/acprof

Chesbrough, H., \& Rosenbloom, R. S. (2002). The role of the business model in capturing value from innovation : evidence from Xerox Corporation's technology spin-off companies. Industrial and Corporate Change, 11 (3), 529555. doi:10.1093/icc/11.3.529

Collis, J., \& Hussey, R. (2005). Pesquisa em Administração: Um guia prático para alunos de graduação e pós-graduação. (2 ${ }^{\text {nd }}$ ed.). Porto Alegre: Bookman.

Creswell, J. W. (2010). Projeto de Pesquisa (2 $2^{\text {nd }}$ ed.). Porto Alegre: Bookman.

Dosi, G. (1982). Technological paradigms and technological trajectories: A suggested interpretation of the determinants and directions of technical change. Research Policy, 11(3), 147-162. doi:10.1016/0048-7333(82)90016-6

Eisenhardt, K. M. (1989). Building theories from case study research. Academy of Management Review, 14(4), 532-550. doi:10.5465/AMR.1989.430 8385 
Enkel, E., Gassmann, O., \& Chesbrough, H. (2009). Open R\&D and Open Innovation: Exploring the phenomenon. R\&D Management, 39(4), 311-316. doi:10.1111/j.1467-9310.2009.00570.x

Feller, J., Finnegan, P., \& Nilsson, O. (2011). Open innovation and public administration: Transformational typologies and business model impacts. European Journal of Information Systems, 20(3), 358-374. doi:10.1057/ ejis. 2010.65

Foss, N. J., \& Saebi, T. (2016). Fifteen years of research on business model innovation: How far have we come, and where should we go? Journal of Management, XX(X), 1-28. doi:10.1177/0149206316675927

Freitas, R. K. V. de, \& Dacorso, A. L. R. (2014). Inovação aberta na gestão pública: Análise do plano de ação brasileiro para a Open Government Partnership. Revista de Administração Pública, 48(4), 869-888. doi:10.1590/ 0034-76121545

Friese, S. (2012). Qualitative data analysis with ATLAS.ti (First). London (UK): Sage Publications.

Johnson, M. W., Christensen, C. M., \& Kagermann, H. (2008, December). Reinventing your business model. Harvard Business Review, 86, 50-59.

Kankanhalli, A., Zuiderwijk, A., \& Tayi, G. K. (2017). Open Innovation in the public sector: A research agenda. Government Information Quarterly, 34(1), 84-89. doi:10.1016/j.giq.2016.12.002

Lambert, S. C., \& Davidson, R. A. (2013). Applications of the business model in studies of enterprise success, innovation and classification: An analysis of empirical research from 1996 to 2010. European Management Journal, 31 (6), 668-681. doi:10.1016/j.emj.2012.07.007

Laursen, K., \& Salter, A. (2006). Open for innovation: The role of openness in explaining innovation performance among U.K. manufacturing firms. Strategic Management Journal, 27(2), 131-150. doi:10.1002/smj.507

Lichtenthaler, U. (2008). Opening up strategic technology planning: extended roadmaps and functional markets. Management Decision, 46(1), 77-91. doi:10.1108/00251740810846752

Lichtenthaler, U., \& Lichtenthaler, E. (2009). A capability-based framework for Open Innovation: Complementing absorptive capacity. Journal of Management Studies, 46(8), 1315-1338. doi:10.1111/j.1467-6486.2009. 00854.x

Marconi, M., \& Lakatos, E. (2003). Fundamentos de metodologia científica. São Paulo: Atlas. doi:10.1590/S1517-97022003000100005 
Massa, L., Tucci, C. L., \& Afuah, A. (2017). A critical assessment of business model research. Academy of Management Annals, 11 (1), 73-104. doi:10.5465/ annals.2014.0072

Nelson, R. R., \& Winter, S. G. (1982). An evolutionary theory of economic change. Cambrigde (MA): Harvard University Press.

Osterwalder, A., \& Pigneur, Y. (2010). Business model generation: A handbook for visionaries, game changers, and challengers. Hoboken (NJ): John Wiley \& Sons.

Osterwalder, A., Pigneur, Y., \& Tucci, C. L. (2005, May). Clarifying business models : Origins, present, and future of the concept. Communications of AIS, 15, 1-40.

Otto, D., Iede, E. T., \& Junior, J. F. P. (2009). Embrapa Floresta: Tecnologias para o desenvolvimento florestal. Colombo (PR): Embrapa.

Pitassi, C. (2012). Inovação aberta na perspectiva das empresas de economias emergentes: Proposta de articulação conceitual. Review of Administration and Innovation, 9(3), 77-102. doi:10.5773/rai.v9i3.678

Rodigheri, H. R., Iede, E. T., Penteado, S., \& Reis Filho, W. (2006). Avaliação dos impactos do programa de manejo integrado de pragas para o controle da vespa-da-madeira em plantios de Pinus no Sul do Brasil. Colombo (PR): Embrapa.

Saebi, T., \& Foss, N. J. (2015). Business models for open innovation: Matching heterogeneous open innovation strategies with business model dimensions. European Management Journal, 33(3), 201-213. doi:10.1016/j. emj.2014.11.002

Schillo, R. S., \& Kinder, J. S. (2017). Delivering on societal impacts through open innovation: a framework for government laboratories. Journal of Technology Transfer, 42(4), 977-996. doi:10.1007/s10961-016-9521-4

Schumpeter, J. (1982). A. Teoria do desenvolvimento econômico: Uma investigação sobre lucros, capital, crédito, juro e o ciclo econômico. São Paulo: Abril Cultural.

Strauss, J. A., \& Corbin, J. (2008). Pesquisa qualitativa: Técnicas e procedimentos para o desenvolvimento de teoria fundamentada. ( $2^{\text {nd }} \mathrm{ed}$.). Porto Alegre: Bookman.

Teece, D. J. (2010a). Business models, business strategy and innovation. Long Range Planning, 43(2-3), 172-194. doi:10.1016/j.lrp.2009.07.003

Teece, D. J. (2010b). Forward integration and innovation: Transaction costs and beyond. Journal of Retailing, 86(3), 277-283. doi:10.1016/j.jretai.2010. 07.013

Van Der Meer, H. (2007). Open innovation-the Dutch treat: Challenges in thinking in business models. Creativity and Innovation Management, 16(2), 192-202. doi:10.1111/j.1467-8691.2007.00433.x 
Vieira Filho, J. E. R. (2009). Inovação tecnológica e aprendizado agrícola : Uma abordagem schumpeteriana (Doctoral dissertation). Retrieved from http:// repositorio.unicamp.br/bitstream/REPOSIP/285683/1/VieiraFilho_Jose EustaquioRibeiro_D.pdf

Vieira, P. A., Buainain, A. M., Torres, D. A. P., \& Contini, E. (2015). A Embrapa e seu papel no sistema nacional de inovação agrícola. Rio de Janeiro: Embrapa.

Wirtz, B. W., Pistoia, A., Ullrich, S., \& Göttel, V. (2015). Business models: Origin, development and future research perspectives. Long Range Planning, 49(10, 36-54.doi:10.1016/j.lrp.2015.04.001

Yin, R. K. (2010). Estudo de caso planejamento e métodos ( $4^{\text {nd }}$ ed.). São Paulo: Bookman.

Yin, R. K. (2001). Estudo de caso: Planejamento e métodos (Vol. 2). São Paulo: Bookman.

Zott, C., Amit, R., \& Massa, L. (2011). The business model: Recent developments and future research. Journal of Management, 37(4), 10191042. doi:10.1177/0149206311406265

\section{AUTHORS NOTE}

Filipe C. Vieira, Department of General and Applied Administration, Universidade Federal do Paraná (UFPR); Hamilcar V. Do Vale, Department of Applied Social Sciences, UFPR; Márcia R. May, Department of General and Applied Administration, Universidade de São Paulo (USP).

Filipe C. Vieira is now Teacher of Distance Learning at Universidade Positivo. Hamilcar V. Do Vale now is Professor of Administration and Accounting at Centro Universitário Opet. Márcia R. May is now Assistant Professor at the Department of General and Applied Administration at UFPR.

Correspondence concerning this article should be addressed to Hamilcar V. do Vale, Rua Nilo Peçanha, 1635, Bom Retiro, Curitiba, Paraná, Brazil, CEP 80520-000.

E-mail: hamilcarh@gmail.com

EDITORIAL BOARD

Editor-in-chief

Silvio Popadiuk

Associated Editor

Thais Vick

Technical Support

Vitória Batista Santos Silva

\section{EDITORIAL PRODUCTION}

Publishing Coordination

Irina Migliari

Editorial Trainee

Maria Luiza Vanz

Copyeditor

Irina Migliari
Language Editor

Daniel Leão

Layout Designer

Emap

Graphic Designer

Libro 